\title{
Detection of Latent Sphaeropsis sapinea Infections in Austrian Pine Tissues Using Nested-Polymerase Chain Reaction
}

\author{
J. Flowers, J. Hartman, and L. Vaillancourt
}

Department of Plant Pathology, 201F Plant Science Building, 1405 Veterens Drive, University of Kentucky, Lexington 40546. Accepted for publication 2 June 2003.

\begin{abstract}
Flowers, J., Hartman, J., and Vaillancourt, L. 2003. Detection of latent Sphaeropsis sapinea infections in Austrian pine tissues using nestedpolymerase chain reaction. Phytopathology 93:1471-1477.

Sphaeropsis sapinea is the causal agent of Sphaeropsis tip blight disease of pines. Past surveys of diseased and symptomless Austrian and Scots pines revealed that latent infections of symptomless shoots by $S$. sapinea are common. The role of these latent infections in the tip blight disease is unknown. A sampling technique and nested-polymerase chain reaction (PCR) protocol were developed to detect latent $S$. sapinea in symptomless pine shoots. The sampling protocol was designed to be

species that were commonly isolated from symptomless pine shoots. The PCR primers also amplified DNA of Botryosphaeria obtusa, which was, however, rare in symptomless Austrian pine tissues. The protocol detected as little as $0.93 \mathrm{pg}$ of $S$. sapinea DNA in terminal bud samples and $10.4 \mathrm{pg}$ of DNA in bark samples. Correlation (chi-square) analyses indicated that the nested-PCR protocol detected latent $S$. sapinea infections in both bud and bark samples with an efficiency that was statistically equivalent to isolating the fungus from the tissue. The nested-PCR protocol will make it possible to more quickly identify latent $S$. sapinea infections in symptomless pine shoots and should be useful in future studies of the latency phenomenon.
\end{abstract} minimally destructive to the shoot so it could be preserved for further studies. The primers that were developed were specific for $S$. sapinea DNA and did not amplify DNA from any of 13 other endophytic fungal
Additional keywords: Diplodia pinea, Diplodia tip blight, endophyte.
During the last decade, Sphaeropsis tip blight (previously known as Diplodia tip blight) has caused significant mortality in Kentucky of landscape Austrian pines (Pinus nigra) and Scots pines (P. sylvestris), and of Scots pine Christmas trees. Sphaeropsis tip blight is caused by the imperfect fungus Sphaeropsis sapinea (Fr.:Fr) Dyko \& Sutton in Sutton (syn. Diplodia pinea (Desmaz.) J. Kickx fil.). The most obvious symptoms of the disease are necrotic, stunted shoot tips and needles. Worldwide, $S$. sapinea infects more than 30 conifer species, which can result in serious economic losses of exotic and native trees in managed plantations $(26,30,36)$. In addition to tip blight, $S$. sapinea can cause seedling damping off and collar rot, root disease, stem cankers, top dieback, and blue stain of cut timber (16-19,27, 28,33).

S. sapinea can be readily isolated from symptomless tissues of both diseased and apparently healthy pine trees $(3,10,25,27)$. Latent $S$. sapinea infections have been reported on various pine hosts and in several different regions of the world $(3,10,25,27)$. Other tree pathogens, including Botryosphaeria spp. causing cankers of woody plants, Cytospora kunzei on conifers, and $\mathrm{Hy}$ poxylon atropunctatum on oak, also have latent phases as part of their life cycles $(1,22,24)$. For all of these pathogens, it has been widely assumed that latent infections can become pathogenic if the host tree becomes stressed (24). Although it was addressed in one study (29), to our knowledge this hypothesis has never been tested directly. If such a transition from latency to pathogenicity actually occurs, it raises some very intriguing questions about the molecular controls of that transition. Our long-term goal is to study the molecular mechanisms of latency, and of the transition from latency to pathogenicity if it occurs, in S. sapinea.

Corresponding author: L. Vaillancourt; E-mail address: vaillan@uky.edu

Publication no. P-2003-0929-02R

(c) 2003 The American Phytopathological Society
The goal of this study was to develop a rapid, reliable, and minimally destructive identification technique for latent $S$. sapinea infections in pine shoots. A polymerase chain reaction (PCR) detection protocol would potentially allow quick, sensitive, and specific screening of symptomless tissues for the detection of latent $S$. sapinea infections. The internal transcribed spacer (ITS) regions of the ribosomal RNA (rDNA) genes have been used to develop species-specific PCR primers for other organisms (11, 12,14,21). The ITS regions are good candidates for development of species-specific primers because they are relatively variable between species (32). Furthermore, the ITS sequences can be amplified from many different fungi by using universal primers that are complementary to the highly conserved flanking regions of the rDNA gene sequences $(14,32)$. Amplification is very efficient because the rDNA gene sequence occurs as multiple copies in the genome (32), and this tends to increase the sensitivity of the PCR (14).

Species-specific primers were developed based on the ITS rDNA region and tested in a nested-PCR protocol for their ability to detect latent $S$. sapinea. The primers also were analyzed for their ability to distinguish $S$. sapinea from other common endophytic and saprophytic fungi found in Austrian pine tissues or as laboratory contaminants. A sampling regime was developed that was minimally destructive to the pine shoots, thus preserving them for further studies. This protocol should be useful for future investigations of the role of latent infections in the Sphaeropsis tip blight disease cycle.

\section{MATERIALS AND METHODS}

Fungal cultures. $S$. sapinea strains used in this study (Table 1) were obtained from other researchers or were isolated from Austrian or Scots pine tissues according to the protocol of Flowers et al. (10). Thirteen species representing the most commonly isolated fungal endophytes from symptomless Austrian pine shoots in 
our area were chosen for this study (Table 1). Penicillium breviocompactum, found growing as a contaminant on a culture plate, also was included. Each fungal isolate was grown according to the protocol of Flowers et al. (10) and single-spored with a micromanipulator device (Microscore LCC, Georgetown, KY). Stock cultures of all single-spored isolates were stored on potato dextrose agar (PDA) slants (Difco Laboratories, Sparks, MD) at $4^{\circ} \mathrm{C}$.

DNA extraction. Fungal stationary cultures were grown in potato dextrose broth (Difco Laboratories) for up to 1 week under ambient laboratory conditions. DNA extraction and purification were performed according to the protocol of Thon et al. (31). DNA pellets were resuspended in $50 \mu \mathrm{l}$ of sterile deionized water. Some DNA samples were further purified by partitioning with phenol and chloroform. All DNA samples were quantified, diluted to $1 \mathrm{ng} / \mu \mathrm{l}$, and stored at $4^{\circ} \mathrm{C}$.

The protocol used to extract DNA from fresh pine tissue was modified from Zhang et al. (34) and Hamelin et al. (12). Fresh Austrian pine tissue samples (described below) were first surfacedisinfested by agitating in a $10 \%$ bleach solution containing a few drops of Tween 20 for $2 \mathrm{~min}$, rinsed twice in sterile deionized water, and then dried by blotting with sterile paper towels. The pine tissue samples were crushed with a mortar and pestle and incubated for $1 \mathrm{~h}$ at $65^{\circ} \mathrm{C}$ in $800 \mu \mathrm{l}$ of DNA extraction buffer with periodic vortexing. After cooling for a few minutes at room temperature, $600 \mu \mathrm{l}$ of chloroform/isoamyl alcohol (24:1) was added to each sample. The samples were vortexed vigorously and then centrifuged. The top aqueous phase of each sample was transferred to a new tube and an equal volume of ice-cold isopropanol was added. The samples were incubated for $10 \mathrm{~min}$ on ice followed by centrifugation. The DNA pellet was washed with $70 \%$ ethanol, air dried, and redissolved in $20 \mu$ of sterile deionized water.

ITS amplification, sequencing, and primer design. PCR was performed using $1 \mu \mathrm{l}$ of fungal DNA as a template. Each $50-\mu \mathrm{l}$ PCR reaction contained $0.5 \mu \mathrm{M}$ ITS5 primer (32), $0.5 \mu \mathrm{M}$ ITS4 primer (32), $2 \mu \mathrm{M}$ dNTPs, $1 \times$ PCR buffer, $5 \mu \mathrm{M} \mathrm{MgCl}_{2}$, and $0.5 \mu$ of Taq DNA polymerase (Invitrogen, Carlsbad, CA). The reactions were incubated for 30 cycles, each consisting of $94^{\circ} \mathrm{C}$ for $30 \mathrm{~s}, 55^{\circ} \mathrm{C}$ for $30 \mathrm{~s}$, and $72^{\circ} \mathrm{C}$ for $30 \mathrm{~s}$. Ten microliters of each PCR reaction product was electrophoresed through a $1 \%$ agarose

TABLE 1. Fungal isolates used in this study

\begin{tabular}{|c|c|c|c|c|c|}
\hline Isolate number & Species & Host & Origin & Collector & GenBank Accession No. \\
\hline $11 \mathrm{~B}$ & Sphaeropsis sapinea & Pinus nigra & Urbana, IL & J. Hartman & AY 156718 \\
\hline $103-1$ & S. sapinea & P. nigra & Lexington, KY & J. Hartman & AY 156719 \\
\hline $113-1$ & S. sapinea & P. sylvestris & Lexington, KY & J. Hartman & AY 156720 \\
\hline $12 \mathrm{~S}$ & S. sapinea & P. nigra & Urbana, IL & J. Hartman & AY 156721 \\
\hline $125-1$ & S. sapinea & P. nigra & Lexington, KY & J. Hartman & AY 156722 \\
\hline $15 \mathrm{SB}$ & S. sapinea & P. nigra & Lexington, $\mathrm{KY}$ & J. Hartman & AY 159245 \\
\hline $150-2$ & S. sapinea & P. sylvestris & Lexington, KY & J. Hartman & AY 159246 \\
\hline $157 \mathrm{D}-1$ & S. sapinea & P. nigra & Lexington, KY & J. Flowers & AY 159247 \\
\hline $157 \mathrm{D}-2$ & S. sapinea & P. nigra & Lexington, KY & J. Flowers & AY 159248 \\
\hline $158 \mathrm{~S}$ & S. sapinea & P. nigra & Lexington, KY & J. Flowers & AY 159249 \\
\hline $158 \mathrm{~N}$ & S. sapinea & P. nigra & Lexington, KY & J. Flowers & AY 159250 \\
\hline $159 \mathrm{~S}$ & S. sapinea & P. nigra & Lexington, KY & J. Flowers & AY 159251 \\
\hline $159 \mathrm{~N}$ & S. sapinea & P. nigra & Lexington, KY & J. Flowers & AY 159252 \\
\hline $144-3$ & S. sapinea & P. sylvestris & Lexington, KY & J. Hartman & AY 159253 \\
\hline $61 \mathrm{SB}$ & S. sapinea & P. nigra & Lexington, KY & J. Hartman & AY 159254 \\
\hline $70 \mathrm{D}$ & S. sapinea & P. nigra & Lexington, KY & J. Hartman & AY 159255 \\
\hline $21 \mathrm{~S}$ & S. sapinea & P. nigra & Lexington, KY & J. Hartman & AY 160196 \\
\hline $25 \mathrm{~B}$ & S. sapinea & P. nigra & Bloomington, IN & J. Hartman & AY 160197 \\
\hline $28 \mathrm{~A}$ & S. sapinea & P. sylvestris & Ohio & J. Hartman & AY 160198 \\
\hline 230 & S. sapinea & P. nigra & Dijon, France & J. Hartman & Not sequenced \\
\hline 232 & S. sapinea & P. nigra & Angers, France & J. Hartman & Not sequenced \\
\hline 233 & S. sapinea & P. nigra & Paris, France & J. Hartman & Not sequenced \\
\hline $128 \mathrm{WI}^{\mathrm{a}}$ & S. sapinea & P. resinosa & Wisconsin & M. Palmer & AF 027758 \\
\hline $411 \mathrm{WI}^{\mathrm{a}}$ & S. sapinea & P. resinosa & Minnesota & M. Palmer & AF 243409 \\
\hline CMW1184 SA ${ }^{a}$ & S. sapinea & P. radiata & South Africa & W. J. Swart & AY 260545 \\
\hline CMW1185 SA ${ }^{\mathrm{a}}$ & S. sapinea & P. radiata & South Africa & W. J. Swart & AY 260544 \\
\hline CMW1187 $\mathrm{SA}^{\mathrm{a}}$ & S. sapinea & P. radiata & South Africa & W. J. Swart & AY 260543 \\
\hline CMW4240 $\mathrm{SA}^{\mathrm{a}}$ & S. sapinea & P. radiata & South Africa & W. J. Swart & AY 260542 \\
\hline $113 \mathrm{WI}^{\mathrm{ab}}$ & S. sapinea & P. banksiana & Wisconsin & G. Adams & AY 160199 \\
\hline $124 \mathrm{WI}^{\mathrm{ab}}$ & S. sapinea & P. banksiana & Wisconsin & M. Palmer & AF 027757 \\
\hline $215 \mathrm{WI}^{\mathrm{ab}}$ & S. sapinea & P. resinosa & Wisconsin & M. Palmer & AF 243410 \\
\hline $457 \mathrm{WI}^{\mathrm{ab}}$ & S. sapinea & P. resinosa & Wisconsin & M. Palmer & AY 160200 \\
\hline 1LEX & Botryosphaeria obtusa & P. nigra & Lexington, KY & J. Flowers & Not sequenced \\
\hline 96-2 WI & B. obtusa & Woody shrub & New York & G. Samuels & AF 027759 \\
\hline 96-115 WI & B. obtusa & Prunus persica & Georgia & K. Britton & AF 243408 \\
\hline B.doth & B. dothidea & P. nigra & Lexington, KY & J. Flowers & AY 160208 \\
\hline L.theo1 & Lasiodiplodia theobromae & P. nigra & Lexington, KY & J. B. Magnin & AY 160201 \\
\hline L.theo 2 & L. theobromae & P. nigra & Lexington, KY & J. Flowers & AY 160214 \\
\hline E.nigr & Epicoccum nigrum & P. nigra & Lexington, KY & J. Flowers & AY 160213 \\
\hline Phoma & Phoma sp. & P. nigra & Lexington, KY & J. Flowers & AY 160204 \\
\hline P.brev & Penicillium breviocompactum & N/A & Lexington, KY & J. Flowers & AY 160203 \\
\hline Fusa1 & Fusarium sp. & P. nigra & Lexington, KY & J. Flowers & AY 160205 \\
\hline Fusa2 & Fusarium sp. & P. nigra & Lexington, KY & J. Flowers & AY 160209 \\
\hline Fusa3 & Fusarium sp. & P. nigra & Lexington, KY & J. Flowers & AY 160207 \\
\hline Pest & Pestalotiopsis sp. & P. nigra & Lexington, KY & J. Flowers & AY 160206 \\
\hline H.dem & Hormonema dematiodes & P. nigra & Lexington, KY & J. Flowers & AY 160202 \\
\hline A.alt & Alternaria alternata & P. nigra & Lexington, KY & J. Flowers & AY 160211 \\
\hline Sord & Sordaria sp. & P. nigra & Lexington, KY & J. Flowers & AY 160210 \\
\hline B.tris & Blakeslea trispora & P. nigra & Lexington, KY & J. Flowers & AY 160212 \\
\hline
\end{tabular}

a WI or SA have been added to the original numbers to distinguish these isolates from those in our own collection.

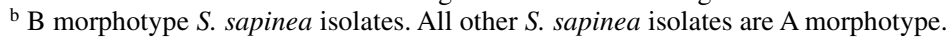


gel and stained with ethidium bromide. Individual PCR products were recovered from the gels for sequencing with a PCR purification kit (QIAquick; Qiagen, Valencia, CA) according to the manufacturer's instructions.

PCR products were sequenced with the Big Dye Terminator Cycle Sequencing Ready Reaction Kit (Applied Biosystems, Foster City, CA), following the manufacturer's protocols, on an automated sequencer (ABI Prism 310; Applied Biosystems).

Sequences were analyzed and a multiple sequence alignment was produced using the Double Twist Gene Tool lite version 1.0 software package (BioTools Inc., Edmonton, Canada). Parameters for the multiple sequence alignment included a gap penalty of 5 and a gap size penalty of 5. All alignments were visually inspected prior to further analysis. Homology searches (GenBank blastn) were performed using the ITS1 and ITS2 regions and the 5.8S rDNA gene of all the fungal isolates. Each of the endophytic or contaminant fungal strains was initially identified based on morphology. Their identities were later confirmed by the results of the homology searches.

Areas of the ITS1 and ITS2 regions that were completely conserved for $S$. sapinea isolates, but divergent in the other fungi, were targeted for $S$. sapinea-specific primer development. Primer pairs were developed using either the PRIME program in the Wisconsin Package (GCG, 1996), or manually, based on visual inspection of the multiple alignment. Potential primer pairs were analyzed for melting temperature, $\mathrm{G} / \mathrm{C}$ content, and primer dimer or hairpin formation using the Integrated DNA Technologies (IDT, Coralville, IA) software package Oligo Analyzer 2.5 and the Cprimers package (G. Bristol and R. Anderson, University of California, Los Angeles).

Nested-PCR. In the first round of the nested-PCR protocol, the universal ITS1 and ITS4 primers (32) were used. Each 50- $\mu$ l reaction contained either $1 \mathrm{ng}$ of purified fungal DNA or $2 \mu \mathrm{l}$ of the DNA extracts from Austrian pine tissue as a template and $0.4 \mu \mathrm{M}$ each ITS primer, $2 \mu \mathrm{M}$ dNTPs, $1 \times$ PCR buffer, $5 \mu \mathrm{M} \mathrm{MgCl}_{2}$, and $0.5 \mu \mathrm{l}$ of Taq DNA polymerase. Sterile water or $1 \mathrm{ng}$ of purified $S$. sapinea DNA was used as a negative or positive control, respectively, in each nested-PCR experiment. The reactions were incubated at $94^{\circ} \mathrm{C}$ for $3 \mathrm{~min}$ followed by 30 cycles each consisting of $94^{\circ} \mathrm{C}$ for $30 \mathrm{~s}, 65^{\circ} \mathrm{C}$ for $15 \mathrm{~s}$, and $72^{\circ} \mathrm{C}$ for $30 \mathrm{~s}$. The resulting PCR product was diluted 1:50 and used as a template for the second round of PCR in the nested-PCR protocol.

The nested-PCR reaction was performed with $2 \mu \mathrm{l}$ of the diluted primary PCR product as a template, and the same PCR conditions as described previously, except $0.375 \mu \mathrm{M}$ each of the $S$. sapineaspecific primers was used in place of the universal ITS primers. Ten microliters of each PCR reaction product was electrophoresed through a $1 \%$ agarose gel and stained with ethidium bromide.

The nested-PCR protocol using the universal ITS primers, ITS1 and ITS4, and the $S$. sapinea-specific nested primers, S.sapFOR3 and S.sapREV3, was evaluated for sensitivity and specificity. Sensitivity was determined by amplifying known concentrations of purified $S$. sapinea genomic DNA in either sterile deionized water; a DNA extract from uninfected 4-year-old greenhousegrown Austrian pine terminal buds; or a DNA extract from uninfected 4-year-old greenhouse-grown Austrian pine bark samples (described below). For each experiment, control pine samples comparable to those used for DNA extraction were incubated on culture media according to Flowers et al. (10) to confirm that the control pines were free of $S$. sapinea infection. PCR control reactions containing only the extracts from the buds or bark, with no added $S$. sapinea DNA, also were included for each experiment.

Purified genomic DNAs from each of the endophytic and contaminant fungi, along with several $S$. sapinea isolates representing different geographic locations, hosts, and morphotypes (A and B), were used to test the specificity of the nested-PCR protocol. Primer specificity was tested further by conducting a GenBank blastn search, using the nested primer sequences as queries, in order to identify sequences from other organisms included in the databases that had the potential to be amplified by the primers.

Sampling of diseased and symptomless Austrian pine tissues. A previous study showed that $S$. sapinea is located primarily within the buds and outer tissues of latently infected Austrian pine shoots (including the bark and phloem tissues down to the cambium) (10). To develop a sampling technique that would be minimally destructive to the shoot, terminal buds and bark samples were chosen as the tissues that would be least likely to cause death of the shoot upon removal.

The distribution of the fungus within the terminal buds and bark of symptomless shoots was evaluated. The entire current year's lignified growth was collected from five symptomless shoots from each of 13 tip blight-diseased trees (a total of 65 shoots) during the late summer of 2001. The samples were placed in individual plastic bags and stored at $4{ }^{\circ} \mathrm{C}$ for no more than 2 days until pathogen isolation. Leafless shoots with their terminal buds still attached were surface-disinfested according to the protocol of Flowers et al. (10). The terminal buds were aseptically removed and then cut longitudinally. A cork borer (0.6-cm-diameter) was used to remove bark disks (including the bark and phloem tissues down to the cambium) from the top ( $1 \mathrm{~cm}$ below terminal bud), middle, and base (1 cm above sampling cut) of each shoot. $S$. sapinea was isolated from the terminal bud halves and bark disks on acidified PDA and subcultured onto water agar plates for verification according to the protocol of Flowers et al. (10).

The distribution of $S$. sapinea within individual bark disk samples was further characterized. Bark disks were removed approximately $1 \mathrm{~cm}$ below the terminal bud from 57 symptomless shoots on three tip blight-diseased Austrian pines. The 57 bark disk samples were surface-disinfested by agitating in a $10 \%$ bleach solution containing a few drops of Tween 20 for 2 min followed by two rinses in sterile deionized water, and then each was cut in half aseptically. Each half was incubated separately to identify $S$. sapinea according to the protocol of Flowers et al. (10).

Analysis of the correlation between culture isolation and nested-PCR. To evaluate the degree of correlation between culture isolation and the nested-PCR protocol, terminal buds and bark samples (from the top of the shoot only) were recovered, as described previously, from 114 symptomless shoots collected from 10 tip blight-diseased Austrian pine trees on the University of Kentucky campus between December 2001 and March 2002. Sixteen terminal bud and 18 bark disk samples were collected from infection-free control Austrian pines that had been grown in the greenhouse for use as negative controls, and three terminal buds and 20 bark disk samples were collected from shoots with symptoms of tip blight in the field for use as positive controls. Each bud or bark sample was cut in half and surface-disinfested as described previously. One half of each sample was incubated on PDA acidified with $1 \mathrm{ml}$ of $85 \%$ lactic acid per liter followed by subculturing of putative $S$. sapinea colonies onto $2 \%$ water agar as described previously (10). The other half of each sample was placed in a 1.5-ml Eppendorf tube and stored at $4{ }^{\circ} \mathrm{C}$ for up to 6 days until the DNA was extracted and used as a template in the nested-PCR protocol described previously. A data set that included only latently infected samples (determined by a positive result for the presence of $S$. sapinea by at least one of the two detection protocols) was used for statistical analysis. A chi-square test was used to compare detection frequency of $S$. sapinea by the culture isolation or the nested-PCR protocol for each sample.

\section{RESULTS}

ITS amplification, sequencing, and primer design. The $5.8 \mathrm{~S}$ rDNA gene and flanking ITS regions of the endophytic and saprophytic fungi were sequenced and compared with the sequences of representative $S$. sapinea isolates (Fig. 1). As expected, most of the variation between species was observed within the ITS1 and 
ITS2 regions. In agreement with previous studies, the ITS sequences of 29 different isolates of $S$. sapinea were virtually identical to one another (data not shown) $(7,15)$. The $S$. sapinea-specific primers S.sapFOR3 (5'-GCTTTGGCGGCTCTTTG-3') and S.sapREV3 (5'-CTACTACGCTTGAGGGCTGAA-3') were chosen from the different primer pairs that were tested as the most sensitive and specific for $S$. sapinea DNA (Fig. 1).

Nested-PCR. The universal ITS primer pair and the S. sapineaspecific primer pair SsapFOR3 and SsapREV3, used in the nested-PCR protocol, amplified a product of approximately $350 \mathrm{bp}$ from the genomic DNA of all 29 S. sapinea isolates tested, including both the A and B morphotypes (data not shown). No product was amplified from any of the endophytic or contaminant fungi with these primers (Fig. 2A).

GenBank blastn search results using each of the $S$. sapineaspecific primers as queries indicated that both sequences were identical to sequences only of $S$. sapinea and the closely related fungus $B$. obtusa. We tested the ability of the primers to amplify DNA from isolates of $B$. obtusa in this study. The nested-PCR protocol amplified a product from the DNA of all three isolates of

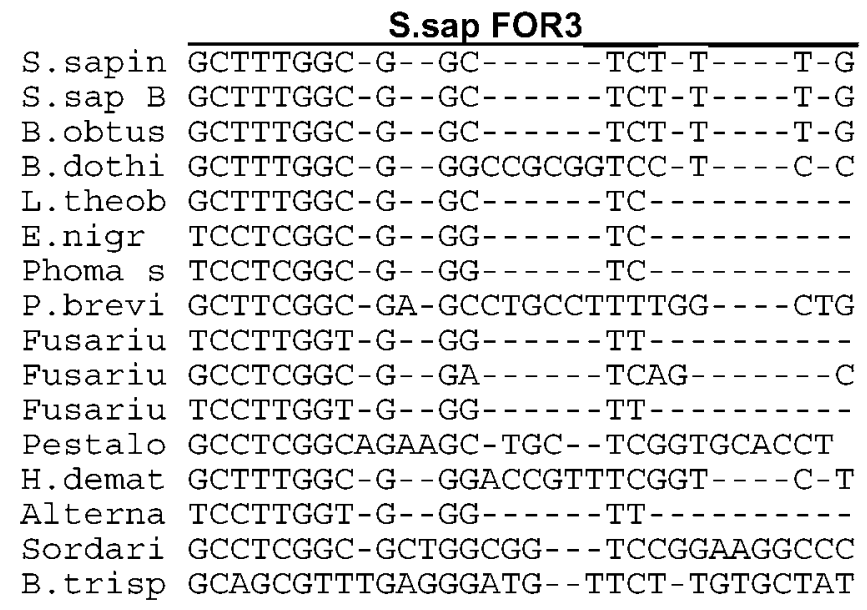

\section{S.sap REV3}

S. sapin CTGTTCAGCC-CTCA-AGCGTA-GTAGAATAC S. sap B CTGTTCAGCC-CTCA-AGCGTA-GTAGAATAC B. obtus CTGTTCAGCC-CTCA-AGCGTA-GTAGAATAC

B. dothi C-GTCTTGCC--TCA-AGCGTA-GTAGAACAT

L. theob CTCTTCAGCC-CTCA-AGCGTA-GTAGAATAC

E.nigr C-GTATTGAT-TTCGGAGCGCA-GTACA-T--

Phoma s C-GTATTGAT-TTCGGAGCGCA-GTACA-T--

P.brevi C-GTCCGGTC-CTCA-AGCGTATGGGGCTTTG

Fusariu C-CTACTGGT-TTCGGAGCGCA-GCACAAGTC

Fusariu CTG--CAGCC-TCCATTGCGTA-GTAGC-TA-

Fusariu C-CTACTGGT-TTCGGAGCGCA-GCACAAGTC

Pestalo CGATAT--CC--TCTGAGCGTA-GTA-ATTTT

$\mathrm{H}$. demat TTCAACCAAC-TTCGG-GCGTA-GTAGAGTTA

Alterna C-CTACTGGT-TTCGGAGCGCA-GCACAAGTC Sordari CTCGCTAGTCACACCGAGCGTA-GTAC--TCT

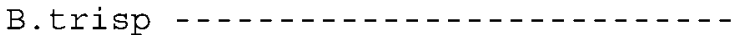

Fig. 1. Multiple sequence alignment of representative Sphaeropsis sapinea isolates, endophytic fungi isolated from Austrian pine, and contaminant fungi. Only the portions encompassing the S.sapFOR3 and S.sapREV3 primers are shown. S.sapFOR3 is located in internal transcribed spacer 1 (ITS1) region and S.sapREV3 is located in ITS2 region. The fungi included in the alignment below, in order of their appearance in the list, are $S$. sapinea (28 A, Kentucky isolate, A morphology); S. sapinea (457, Wisconsin isolate, B morphology); Botryosphaeria obtusa; Botryosphaeria dothidea; Lasiodiplodia theobromae (L.theo1); Epicoccum nigrum; Phoma sp.; Penicillium breviocompactum; Fusarium sp. 1; Fusarium sp. 2; Fusarium sp. 3; (none of these three Fusarium spp. were further identified), Pestalotiopsis sp., Hormonema dematiodes; Alternaria alternata; Sordaria sp.; and Blakeslea trispora. More information about each of these isolates can be found in Table 1.
B. obtusa tested (Table 1). This product was the same size as that produced by amplification of $S$. sapinea DNA (Fig. 2B). The GenBank blastn searches also indicated that the SsapFOR3 and SsapREV3 primer sequences differ from $S$. sapinea f. sp. cupressi and $B$. stevensii by only $1 \mathrm{bp}$ (close to the $3^{\prime}$ end of primer S.sapFOR3). Thus, it is likely that these primers could also amplify a product from the genomic DNA of these fungi, which are, however, not known to infect Pinus spp. We did not test this possibility experimentally.

The sensitivity of the nested-PCR protocol depended on the source of the sample. A PCR product of the expected size was amplified from as little as $0.5 \mathrm{pg}$ of purified $S$. sapinea genomic DNA per $\mu$ of diluted in sterile deionized water, but sensitivity dropped slightly, to $0.93 \mathrm{pg} / \mu \mathrm{l}$, for purified genomic DNA diluted in bud extract, and was reduced about 20 -fold, to $10.4 \mathrm{pg} / \mu \mathrm{l}$, for purified genomic DNA diluted in extract from bark samples (Fig. 3).

Pathogen distribution of $S$. sapinea within symptomless terminal buds and bark samples. Of the 65 symptomless Austrian pine shoots that were tested, $50(77 \%)$ were latently infected by $S$. sapinea, as determined by isolation in culture. S. sapinea was isolated from $26(52 \%)$ of the terminal buds taken from the latently infected shoots and from at least one of the three bark samples in $39(78 \%)$ of the shoots. S. sapinea was most frequently recovered from bark samples taken from the top of the shoots (data not shown). There was a highly significant chi-square probability of 0.0094 that the position of the sample at the top of the shoot and the presence of $S$. sapinea were interdependent. Therefore, for subsequent experiments bark disks were taken only from the tops of the shoots.

Pathogen distribution of $S$. sapinea in terminal buds and bark samples. The distribution of $S$. sapinea within terminal bud and bark samples appeared to be discontinuous. The fungus was isolated from both halves of only 13 of 26 bisected, latently infected terminal buds. S. sapinea was isolated from only one of the two halves in the remainder of the samples. Of the 57 bark samples that were bisected and tested in culture, 41 (72\%) were latently infected with $S$. sapinea. The fungus was isolated from both halves of these latently infected bark samples two-thirds of the time. In the remaining third of the samples, S. sapinea could be isolated from only one of the two halves.

Correlation between culture isolation and nested-PCR. The ability of the nested-PCR protocol to detect latent $S$. sapinea shoot infections was compared statistically with the culture isolation technique by a chi-square analysis. The terminal bud and/or the bark were colonized by $S$. sapinea in 101 shoots of 114 sampled (89\%). S. sapinea was isolated from $96 \%$ of the bark samples taken from these latently infected shoots and from $38 \%$ of the terminal buds. The correlation between results obtained by culture isolation and by the nested-PCR protocol was highest for the bark tissue (Fig. 4). This correlation was statistically highly significant, with a chi-squared probability of $0.003(<0.05$ is statistically significant). All control samples removed from infection-free greenhouse-grown Austrian pines tested negative for the presence of $S$. sapinea with both the culture isolation technique and the nestedPCR protocol. All control Austrian pine tissues with symptoms of tip blight taken from the field tested positive for the pathogen by both detection techniques.

\section{DISCUSSION}

In this study, a sampling technique and a nested-PCR protocol were developed that can rapidly and accurately detect $S$. sapinea in symptomless pine shoots while preserving the latently infected shoots for further study. This is an improvement over previously published methods that are more time-consuming and destructive.

Members of the species Pinus subgenus Diploxylon, which includes Austrian and Scots pines, are reportedly colonized by many fungal endophytes (13). In developing a PCR detection protocol, it 
was important to ensure that the PCR primers did not amplify the DNA of common fungal endophytes. The endophytic fungal isolates chosen for this analysis were those most commonly cultured in no more than 1 week from symptomless, surface-disinfested Austrian pine tissue in our area. With the exception of Blakeslea trispora, all of these fungi have been reported previously as endophytes on pine tissue $(5,6,9,20,22-25)$. Penicillium breviocompactum is a common laboratory contaminant and was included for that reason. The pair of PCR primers developed for this study, S.sapFOR3 and S.sapREV3, was specific for S. sapinea and did not amplify a product from any of the other cultured endophytic or saprophytic fungi tested.

The primers developed for this study amplified a product of equal size from strains of both the A and B morphotypes of $S$. sapinea. Although representative strains were not tested, the $\mathrm{C}$ morphotype of $S$. sapinea, which has an ITS sequence that is identical to that of the A morphotype (8), also would be expected to be amplified by these primers. Type B isolates are morpho- logically distinct from type A and are less aggressive on red and jack pines (2). Type $\mathrm{C}$ isolates are more similar to type $\mathrm{A}$ isolates but they have been found only in Indonesia $(4,8)$. A type B isolate was reportedly isolated in Kentucky from a Virginia pine (28), but the thousands of isolates of $S$. sapinea that we have recovered over the past several years from diseased and symptomless Austrian pine tissues have all had the typical type A morphology. It is important to note that we have not characterized these isolates further by using molecular markers, which would be a more accurate method for assigning morphotype. However, it seems likely that B and C isolates are rare or nonexistent in Austrian pines in Kentucky, and so their ability to react with the $S$. sapinea primers should not seriously impact the future use of this assay to detect latent infections in our regional population of Austrian pines.

Results of a GenBank blastn homology search indicated that the $S$. sapinea-specific primers would also probably amplify a product from the genomic DNA of the fungus B. obtusa. This prediction

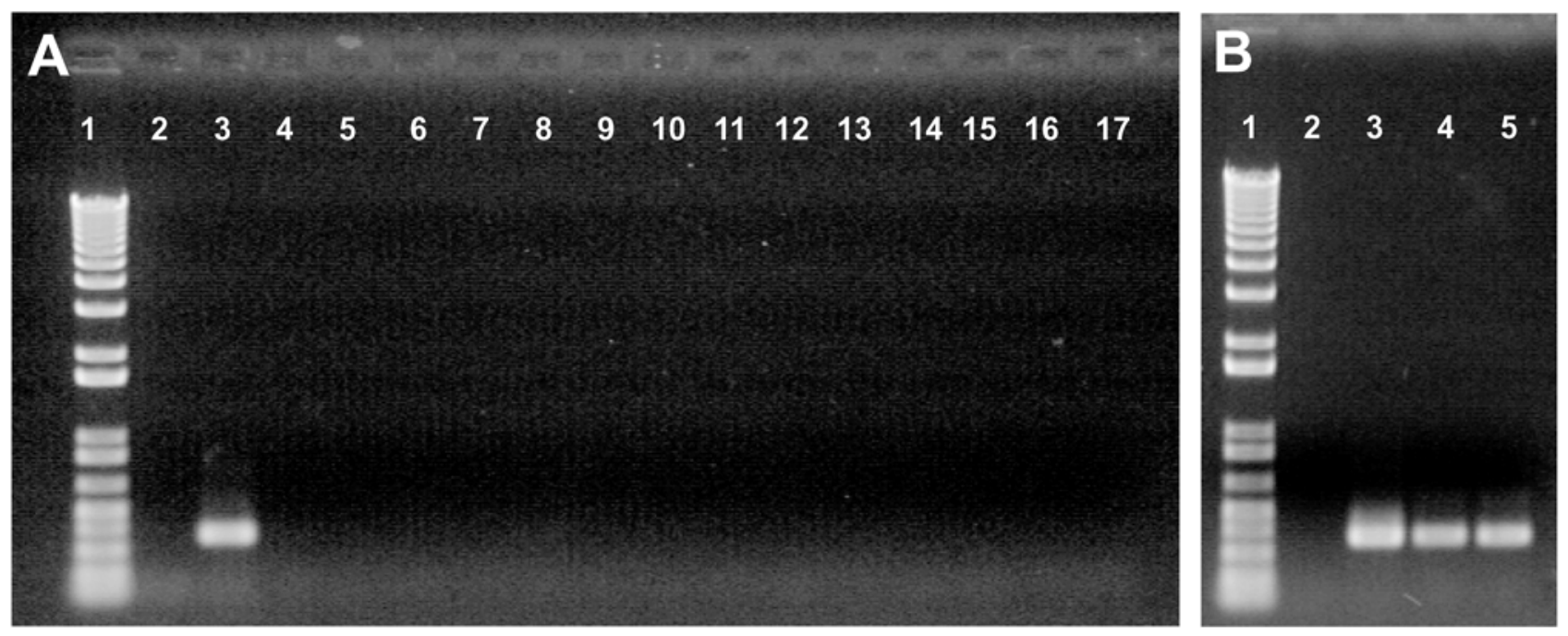

Fig. 2. Nested-polymerase chain reaction products amplified from purified genomic DNAs of Sphaeropsis sapinea, Botryosphaeria obtusa, and various pine endophytic fungi. A, Lane 1, 1-kb Plus Ladder (Invitrogen, Carlsbad, CA); lane 2, negative control (no DNA template); lane 3, S. sapinea (0.45 ng); lane 4, B. dothidea (1 ng); lane 5, Lasiodiplodia theobromae 1 (1 ng); lane 6, L. theobromae 2 (1 ng); lane 7, Fusarium sp. 1 (1 ng); lane 8, Fusarium sp. 2 (1 ng); lane 9, Fusarium sp. 3 (1 ng); lane 10, Epicoccum nigrum (1 ng); lane 11, Phoma sp. (1 ng); lane 12, Penicillium brevicompactum (1 ng); lane 13, Pestalotiopsis sp. $(1 \mathrm{ng})$; lane 14, Hormonema dematiodes $(1 \mathrm{ng})$; lane 15, Alternaria alternata $(1 \mathrm{ng}) ;$ lane 16, Sordaria $\mathrm{sp} .(1 \mathrm{ng})$; and lane 17, Blakeslea trispora $(1 \mathrm{ng})$. B, Lane 1, 1-kb Plus Ladder (Invitrogen); lane 2, negative control (no DNA template); lane 3, S. sapinea (0.45 ng); lane 4, B. obtusa 96-2 WI (1 ng); and lane 5, B. obtusa 96-115 WI (1 ng).

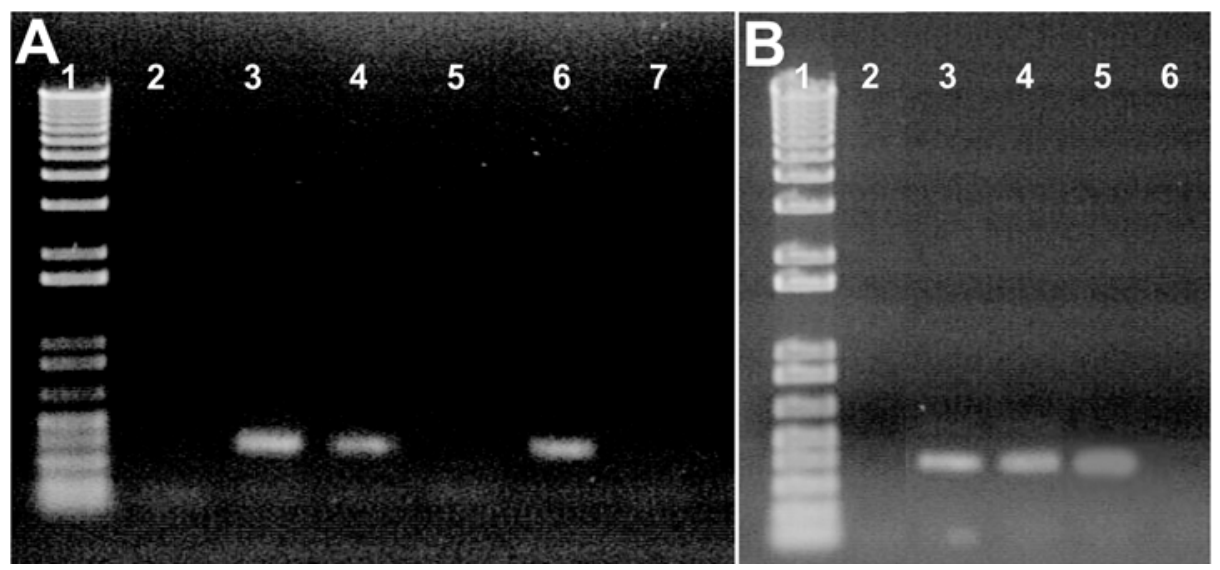

Fig. 3. Nested-polymerase chain reaction detection of A, purified Sphaeropsis sapinea DNA diluted in sterile deionized water (lanes 3 to 5) or DNA extracts from $S$. sapinea infection-free Austrian pine terminal buds (lanes 6 and 7), or B, DNA extracts from $S$. sapinea infection-free Austrian pine bark plugs (lanes 2 to 6). A and B, Lane 1 contains 1-kb Plus Ladder (Invitrogen, Carlsbad, CA). A, Lane 2, negative control (no DNA template); lane 3, 0.05 ng of DNA; lane 4, $0.5 \mathrm{pg}$ of DNA; lane 5, $0.05 \mathrm{pg}$ of DNA; lane 6, $0.9 \mathrm{pg}$ of DNA; and lane 7, $2 \mu \mathrm{l}$ of DNA extract from infection-free control Austrian pine terminal buds. B, Lane 2, negative control (no DNA template); lane 3, 64 pg of DNA; lane 4, 26 pg of DNA; lane 5, 10.4 pg of DNA; and lane 6, $2 \mu 1$ of DNA extract from infection-free control Austrian pine bark plugs. 
was subsequently tested and confirmed. B. obtusa is common in temperate regions on many hosts, including pine $(4,9)$. It produces a serious canker disease of apples (24) but it is not known to cause tip blight symptoms on pine. B. obtusa and $S$. sapinea are closely related (15). The sexual stage of $S$. sapinea is unknown, but the teleomorphs of Sphaeropsis spp. are often Botryosphaeria spp. (35). B. obtusa and $S$. sapinea have similar, though distinguishable, colony and spore morphology and can easily be confused (15). The two fungi have virtually identical rDNA sequences, with only 2 bp differences within the 5.8S rDNA gene. Unfortunately, neither of these changes is located in a region that would be suitable for primer development, so it is unlikely that a primer pair could be designed based on the rDNA sequences that would distinguish among these two fungi. It is possible that some pine shoots could be falsely identified by the nested-PCR method as containing latent $S$. sapinea infections when they actually contain B. obtusa. However, our data suggest that the percentage of such false positives is likely to be very small. More than 1,300 symptomless shoots from both Austrian and Scots pine have been tested for the presence of $S$. sapinea by culture isolation in our laboratory since 1998. The anamorphic state of B. obtusa has been isolated only twice from among those 1,300 shoots, once from a nondisinfested Austrian pine shoot and once from a surfacedisinfested Scots pine shoot. The identification of B. obtusa was initially based on spore morphology which was then confirmed by sequencing of the ITS regions. Other results of the Blastn search suggest that the $S$. sapinea primers might also amplify a product from the DNA of $S$. sapinea f. sp. cupressi or B. stevensii, both of which differ from the primer sequences by only a single base pair. Since these species have not been reported to occur on pine, we did not test this prediction experimentally.

The nested-PCR protocol described here amplified a detectable product from as little as $0.5 \mathrm{pg}$ of purified $S$. sapinea DNA per $\mu$. However, sensitivity was substantially reduced (by about 20 -fold) when purified $S$. sapinea DNA was diluted in DNA extracts of bark tissue from infection-free Austrian pine trees that had been grown in the greenhouse. This suggests that pine bark tissues contain inhibitors of the PCR reaction. Nevertheless, the high degree of correlation between culture isolation and the PCR technique using bark disk samples demonstrates that most latently infected tissue samples contain enough $S$. sapinea DNA for successful amplification. Thus, the presence of inhibitors does not appear to be a significant impediment to the use of this protocol for detection of latent $S$. sapinea infections.

An important goal of this study was to develop a less destructive sampling protocol that would preserve latently infected shoots

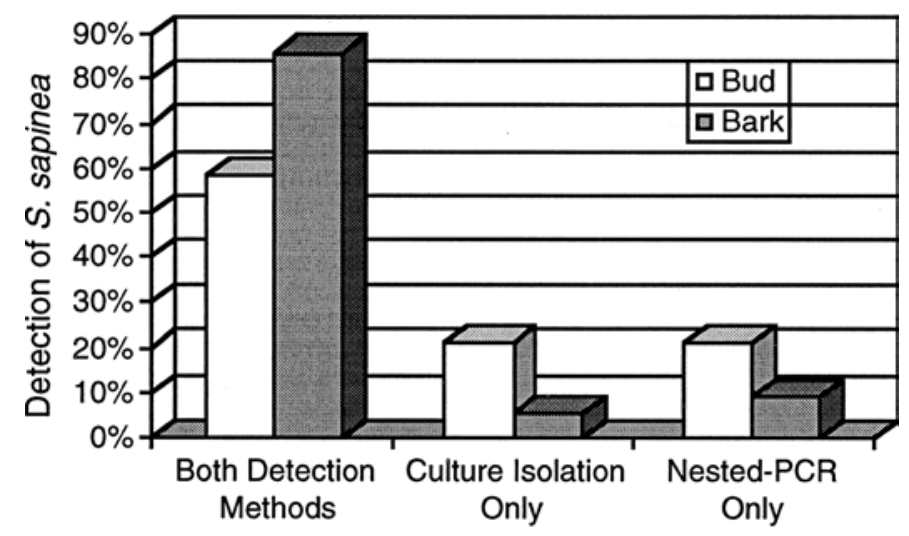

Fig. 4. Comparison of the culture isolation and the nested-polymerase chain reaction techniques for detection of Sphaeropsis sapinea in symptomless, latently infected Austrian pine terminal buds or bark samples. Of the 114 symptomless shoots sampled, 101 were latently infected with S. sapinea, indicated by a positive result using one or both techniques. Only these 101 latently infected shoots are represented in the figure. for further study. A previous study found that S. sapinea was located primarily within the outer tissues (including terminal and lateral buds, bark and phloem tissue down to the cambium, and needle bundles) of latently infected shoots (10). Initially, needles were considered an ideal tissue for sampling, but we found that the needles were rarely latently infected (J. Flowers, unpublished data). A large majority (96\%) of the bark disks that were removed from symptomless, latently infected shoots on diseased trees in our correlation study were colonized by $S$. sapinea. This is in contrast to the lower colonization rate $(38 \%)$ for terminal buds. The intact shoots from which a bark plug had been removed for the present study were observed in the field 10 months later, and all of the shoots appeared healthy, with the cork-borer wounds completely calloused over. Thus, the most suitable sample for nondestructive detection of latent $S$. sapinea shoot infections seems to be a bark disk that is removed from the top of the shoot with a cork borer.

The nested-PCR technique was statistically equivalent to the culture isolation technique for detection of latent $S$. sapinea infections. Uneven distribution of the pathogen is one likely explanation for cases in which results of the two methods were not correlated. The pathogen appears to be discontinuous in both bud and bark tissues, as suggested by the finding that $S$. sapinea could be isolated from both halves of a terminal bud only $50 \%$ of the time and from both halves of a bark disk only $66 \%$ of the time. Another possibility is overgrowth of $S$. sapinea in culture by other endophytic fungi or bacteria, preventing it from being identified in the culture dish. The nested-PCR technique can theoretically amplify DNA from dead $S$. sapinea cells, which could explain why some samples were positive with the nested-PCR technique but not with the culture isolation. Spurious amplification in the PCR cannot be ruled out as another possible explanation for cases in which the two methods did not agree, although negative controls produced from uninfected samples were included and always failed to detect any contamination.

As more laboratories begin to use molecular techniques for plant disease diagnosis, the nested-PCR protocol could replace culture isolation for the quick diagnosis of Sphaeropsis tip blight. However, symptoms and signs of this disease are easily recognized in landscape Austrian and Scots pines. When pathogen identification is needed, the primary advantage of the nested-PCR technique is that it can positively identify the pathogen within 1 day. It can, therefore, provide a confirmation of the initial diagnosis much more quickly than culturing, which takes about 3 weeks. Disadvantages include the increased cost of PCR over culturing and the requirement for more specialized technical expertise.

A combination of the nested-PCR technique described here and culture isolation could enhance the efficiency of certification programs designed to identify disease-free nursery stock. However, it is very important to emphasize that both techniques can produce false negative results. Due to sampling issues and the apparently discontinuous nature of $S$. sapinea in symptomless shoots, we feel it would be inappropriate to use either or both of these procedures to guarantee that nursery stock was completely free of $S$. sapinea colonization.

The hypothesis that latent $S$. sapinea infections become pathogenic when the host becomes stressed has yet to be tested directly. Barriers to addressing this question in the past have included the relatively long periods of time required to identify latently infected shoots by culturing, limiting the number of samples that can be tested, and the destruction of the whole shoot in the process. With the sampling and nested-PCR protocol developed here, latently infected shoots can now be identified less destructively and far more quickly. These latently infected shoots could be manipulated to simulate various stresses and then observed for tip blight symptom development. Future experiments of this type should provide important insights into the possible role of latent infections in the Sphaeropsis tip blight disease cycle. 


\section{ACKNOWLEDGMENTS}

Paper number 03-12-123 from the Kentucky Agricultural Experimental Station, published with the permission of the director. We thank the Kentucky Nursery/Landscape Fund and the University of Kentucky for financial support; J. Bernard Magnin and S. Pauly, undergraduate students at ENESAD de Dijon in France, who contributed greatly to this work during summer exchange visits to Lexington in 2001; D. Smith and G. Stanosz at the University of Wisconsin, Madison, and G. Koening at the University of Pretoria, South Africa, for donation of fungal isolates; D. Brown and E. Nuckles for excellent technical support; and the anonymous reviewers for helpful suggestions.

\section{LITERATURE CITED}

1. Bassett, E. N., and Fenn, P. 1984. Latent colonization and pathogenicity of Hypoxylon atropunctatum on oaks. Plant Dis. 68:317-319.

2. Blodgett, J. T., and Stanosz, G. R. 1997. A and B morphotypes of Sphaeropsis sapinea differ in aggressiveness, but both infect nonwounded red or jack pines. Plant Dis. 81:143-147.

3. Botes, W. M., Swart, W. J., and Crous, P. W. 1996. Frequencies of fungal endophytes isolated from pine needles in South Africa. (Abstr.) Phytopathology 86(suppl.):S66.

4. Burgess, T., Wingfield, M. J., and Wingfield, B. W. 2001. Simple sequence repeat markers distinguish among morphotypes of Sphaeropsis sapinea. Appl. Environ. Microbiol. 67:345-362.

5. Carroll, G. C. 1995. Forest endophytes: Patterns and process. Can. J. Bot. 73:S1318-S1324.

6. Carroll, G. C., and Carroll, F. E. 1978. Studies on the incidence of coniferous needle endophytes in the Pacific Northwest. Can. J. Bot. 56:3034-3043.

7. de Wet, J., Wingfield, M. J., Coutinho, T., and Wingfield, B. 2000. Characterization of Sphaeropsis sapinea isolates from South Africa, Mexico, and Indonesia. Plant Dis. 84:151-156.

8. de Wet, J., Wingfield, M. J., Coutinho, T., and Wingfield, B. 2002. Characterization of the "C" morphotype of the pine pathogen Sphaeropsis sapinea. For. Ecol. Manag. 161:181-188.

9. Farr, D. F., Bills, G. F., Chamuris, G. P., and Rossman, A. Y. 1989. Fungi on Plants and Plant Products in the United States. The American Phytopathological Society, St. Paul, MN.

10. Flowers, J., Nuckles, E., Hartman, J., and Vaillancourt, L. 2001. Latent infection of Austrian and Scots pine tissues by Sphaeropsis sapinea. Plant Dis. 85:1107-1112.

11. Hamelin, R., Berube, P., Gignac, M., and Bourassa, M. 1996. Identification of root rot fungi in nursery seedlings by nested multiplex PCR. Appl. Environ. Microbiol. 62:4026-4031.

12. Hamelin, R., Bourassa, M., Rail, J., Dusabenyagasani, M., Jacobi, V., and Laflamme, G. 2000. PCR detection of Gremmeniella abietina, the causal agent of Scleroderris canker of pine. Mycol. Res. 104:527532.

13. Hata, K., and Futai, K. 1996. Variation in fungal endophyte populations in needles of the genus Pinus. Can. J. Bot. 74:103-114.

14. Henson, J. M., and French, R. 1993. The polymerase chain reaction and plant disease diagnosis. Annu. Rev. Phytopathol. 31:81-109.

15. Jacobs, K. A., and Rehner, S. A. 1998. Comparison of cultural and morphological characters and ITS sequences in anamorphs of Botryosphaeria and related taxa. Mycologia 90:601-610.
16. Nicholls, T. H., and Ostry, M. E. 1990. Sphaeropsis sapinea cankers on stressed red and jack pines in Minnesota and Wisconsin. Plant Dis. 74:54-56.

17. Palmer, M. A. 1991. Isolate type of Sphaeropsis sapinea associated with main stem cankers and top-kill of Pinus resinosa in Minnesota and Wisconsin. Plant Dis. 75:507-510.

18. Palmer, M. A., and Nicholls, T. H. 1985. Shoot blight and collar rot of Pinus resinosa caused by Sphaeropsis sapinea in forest tree nurseries. Plant Dis. 69:739-740.

19. Peterson, G. W. 1977. Infection, epidemiology, and control of Diplodia tip blight of Austrian, ponderosa, and Scots pines. Phytopathology 67:511-514.

20. Petrini, O., and Fisher, P. J. 1988. A comparative study of fungal endophytes in xylem and whole stem of Pinus sylvestris and Fagus sylvatica. T. Brit. Mycol. Soc. 91:233-238.

21. Schmidt, O., and Moreth, U. 2000. Species-specific PCR primers in the rDNA-ITS region as a diagnostic tool for Serpula lachrymans. Mycol. Res. 14:69-72.

22. Schoeneweiss, D. F. 1983. Drought predisposition to Cytospora canker in blue spruce. Plant Dis. 67:383-385.

23. Sieber, T. N., Rys, J., and Holdenreider, O. 1999. Mycobiota in symptomless needles of Pinus mugo ssp. uncinata. Mycol. Res. 103:306-310.

24. Sinclair, W. A., Lyon, H. H., and Johnson, W. T. 1987. Diseases of Trees and Shrubs. Cornell University Press, Ithaca, NY.

25. Smith, H., Wingfield, M. J., Crous, P. W., and Coutinho, T. A. 1996. Sphaeropsis sapinea and Botryosphaeria dothidea endophytic in Pinus spp. in South Africa. S. Afr. J. Bot. 62:86-88.

26. Stanosz, G. R., and Cummings Carlson, J. 1996. Association of mortality of recently planted seedlings and established saplings in red pine plantations with Sphaeropsis collar rot. Plant Dis. 80:750-753.

27. Stanosz, G. R., Smith, D. R., Guthmiller, M. A., and Stanosz, J. C. 1997. Persistence of Sphaeropsis sapinea on or in asymptomatic shoots of red and jack pines. Mycologia 89:525-530.

28. Stanosz, G. R., Swart, W. J., and Smith, D. R. 1999. RAPD marker and isozyme characterization of Sphaeropsis sapinea from diverse coniferous hosts and locations. Mycol. Res. 103:1193-1202.

29. Stanosz, G. R., Blodgett, J. T., Smith, D. R., and Kruger, E. L. 2001. Water stress and Sphaeropsis sapinea as a latent pathogen of red pine seedlings. New Phytol. 149:531-538.

30. Swart, W. J., and Wingfield, M. J. 1991. Biology and control of Sphaeropsis sapinea on Pinus species in South Africa. Plant Dis. 75:761-765.

31. Thon, M., Nuckles, E., and Vaillancourt, L. 2000. Restriction enzymemediated integration used to produce pathogenicity mutants of $\mathrm{Col}$ letotrichum graminicola. Mol. Plant-Microbe Interact. 13:1356-1365.

32. White, T. J., Bruns, T., Lee, S., and Taylor, J. 1990. Amplification and direct sequencing of fungal ribosomal RNA genes for phylogenetics. Pages 315-322 in: PCR Protocols: A Guide to Methods and Applications. Academic Press, New York.

33. Wingfield, M. J., and Knox-Davies, P. S. 1980. Association of Diplodia pinea with a root disease of pines in South Africa. Plant Dis. 64:221-223.

34. Zhang, Y., Uyemoto, J. K., and Kirkpatrick, B. C. 1998. A small-scale procedure for extracting nucleic acids from woody plants infected with various phytopathogens for PCR assay. J. Virol. Methods 71:45-50.

35. Zhou, S., Smith, D., and Stanosz, G. 2001. Differentiation of Botryosphaeria species and related anamorphic fungi using inter simple or short sequence repeat (ISSR) fingerprinting. Mycol. Res. 105:919-926.

36. Zwolinski, J. B., Swart, W. J., and Wingfield, M. J. 1995. Association of Sphaeropsis sapinea with insect infestation following hail damage of Pinus radiata. For. Ecol. Manag. 72:293-298. 